\title{
Exploring the Effectiveness of Glog in Language Learning
}

\author{
https://doi.org/10.3991/ijet.v14i11.10217 \\ Anitha Devi V $(\bowtie)$ \\ Vellore Institute of Technology, Vellore, India \\ vanithadevi@vit.ac.in
}

\begin{abstract}
This paper reports the purpose of integrating Web 2.0 tool, Glogster in language learning tasks. Web 2.0 tools and digital blooms taxonomy have become prevalent in the English classroom with the ubiquitous use of smartphone, tabs and laptops in the language classroom. Certain details in this paper were presented in the Connecting Online (CO12) session in the year 2012. This paper also describes activities which would help in fostering creativity and autonomy in the teaching-learning process. Glogster is a web 2.0 tool which provides a platform for teachers and learners in creating and using glogs for language learning and other subjects. This tool provides a supportive platform for monitoring project based language learning activities. Having studied the use of the glog for language learning with the first batch of 54 students in 2009, in the following semesters 302 students were introduced to the glogging task. In total, 356 B.Tech students at VIT were introduced to web 2.0 tools for language learning tasks. They were introduced to the use of three Glogster tasks for synthesizing their real life and virtual language learning experiences in different semesters.
\end{abstract}

Keywords-Glogster, Multimodal task, Digital learners.

\section{$1 \quad$ Introduction}

This paper focuses on the use of computers, internet, glogster in language learning classes. The tasks can be categorized under integrative computer assisted language learning activities. Integrative Computer Assisted Language Learning (CALL) allows learners to learn by exploring all the language skills including grammar and pronunciation skills through various multimedia materials. The following section discusses the development of integrative computer assisted language learning.

\subsection{Integrative computer assisted language learning (CALL)}

According to Lehrers (1993), learners have the advantage of exploring information through multiple layers while using computer based tools. But Mann (1995) reports that text and sound is the most effective stimulus for learning through hypermedia. Various learning environments have been experimented to check the effectiveness of 
synchronous and asynchronous Computer Assisted Language Learning tasks. All the approaches, behaviourist to integrative Warschauer (1996) have not completely overruled any approach while web 2.0 has proliferated largely into the zones of language learning. Most of the CALL approaches either complement or supplement each other as the technological devices and gadgets have advanced increasing the ubiquitous nature of the technology driven learning environment. New models of teaching evolve as teachers understand the learners needs (Pennycook 1989; Kern and Warschauer, 2000; 1996; Shetzer and Meloni, 2000; Warschauer and Cook 1999) considering factors from education and corporate world. Other tasks focus on socio-cognitive activities, research tasks based on international topics or content related tasks and make a website of known firms. Self-access (Joshi, 2011), Self-instruction (Benson, 2007); Self-regulation (Dörnyei, 2005) are factors which are important for developing autonomy for learners while language learning. Computers, internet (Joshi, 2011) promote autonomous learning environment allowing the learners to be engaged and the same is evident with smart phones and mobile apps which have become more popular among students who are digital learners.

\section{Digital Learners}

The Digital Literate and Digital Native refer to students who have started adapting new smartphones and digital technologies between 2008 and 2014 at VIT, Vellore. They belong to the generation $\mathrm{z}$ learners whose learning modalities conform to connectionist theories.

Language teachers have to catch up with models that relates to connectionist theories. Some observations of connectivism are:

- Networking

- Being connected

- Collaborating

- Sharing and learning

Knowledge of Glog is part of this digital literacy and connectivism, where people learn to search for information in the internet and also exercise autonomous learning by innovative presentation and collating creativity.

The digital natives will show different expertise in classrooms while learning. They will be able to solve complex problems using different levels of their brains. The future generation of learners is far more liberated than the learners of the 1950s or even until the 1990s (Vance Stevens 2007, Lawrence Lessig 2006, Grossman 2006). The learners are socially networked and their expectations are different. They cannot just be engaged in listening to teacher talk. The leaner shows the attitude: "enrage me or engage me!" (Prensky 2005) with their teachers. Language Activities like creating a Glogster on picture based grammar learning activity conform to the "engage me" category of learner activities. The Web 2.0 tool, Glog engages the learner completely with fun and knowledge because the learners synthesize, create and write their description using pictures. They also enjoy, collaborate and interact to focus on using 
appropriate prepositions while they describe the picture in the first group task. All the students of the 2009 English for Engineers class do not have smartphones. Only two students have smartphones because these kinds of smartphones were not commonly available for the common public. In the consecutive years, as technology advanced these phones were commonly available to everybody. So understanding the significance of glog in the language learning tasks was necessary through classroom research led to the construction of the null hypothesis for this study. There is no significance in using glogster, the web 2.0 tool for increasing the motivation level of L2 learners to complete English assignments on grammar.

\subsection{Glogster}

Glog is almost like a collage or a poster. It is a digital collage which allows the user to insert multimedia. Creating a glog is simple because one has to drag and drop multimedia elements like text, audio, video, images, graphics, drawings, and data. "A Glog is created using a very easy to understand, drag and drop interface that is relevant, enjoyable, and scalable for students of all ages and learning styles." (Glogster, 2007) It is interactive and visually appealing to the user. A glog is an interactive poster that is accessed online through the website glogster (Baker and Wills 2013). A glog can be created similar to a webpage which adheres to a particular concept. Similar to a webpage, glogster offers colourful artistic backgrounds, clip art and animations.

Martin Santorcl, Patrik Prepsl and Roman Smola developed Glogster in 2007 and Glogster EDU was developed in 2009 to offer a secure and specific platform for education. Eduglog can be used for educational purposes, Glogster EDU is a platform for teachers and students to collaborate, to unleash their creativity, ideas and skills. The website for Glogster EDU is http://glogsteredu.edu.glogster.com/glog-edu/. Glogster has the features like galleries with wall designs called as 'Glog wall' and 'Page wall'.

The Glog has galleries in which graphics and images of frames and walls are readily available. Drawing new images is also possible. Videos, Audios, documents and data can be inserted from other websites. All these features can be placed on the digital poster anywhere in a visually appealing manner. According to the Glogster EDU website, around 7,000,000 people are experiencing the benefits of this learning environment. Everybody becomes a digital native making the environment green (Glogster EDU, 2009).

Glogster is part of a new emerging literacy practice found outside the language classroom. Blogs, Blogging, and Bloggers are terms quite familiar to many students and teachers. We have research articles on blogging and ESL students. Glogster is similar to these blogs but allows dynamic texts with multimedia. Reading and comprehending such multimodal texts is integral part of honing multiliteracy skills.

Teachers encounter students who cannot be involved with interest using the print medium only. They are truly multimodal and quick in comprehending digital pages. So activities need to be compositions which involve different media. The process of composing on a glog invokes multimodal expressions which creates paths in effective comprehension. The easy to use tools and features inspire the learner to unleash creativity while learning. 
Stoeckle and Muilenburg (2012) describe the use of an interactive poster website, glogster, to assist students in creating the event projects. It has been shown that there is a positive correlation with peer discussion of current events and civic participation. Hence it is essential for the students to have early exposure to the current events and group discussion. The possible usefulness of virtual current events compared to standard written current events is also discussed in their work.

Leiva et.al (2009) characterized the glog-normal distribution and presents a comprehensive treatment of the properties of this model. They present the probability density function as well as a graphical analysis of this density, the cumulative distribution function and the moments for this statistical distribution. Additionally, by using likelihood methods they estimate the parameters, carry out asymptotic inference and discuss influence diagnostics of this model. They also the usefulness of the glognormal distribution for modeling gene expression microarray intensity data by means of a real numerical example.

Kent (2010) has conducted a study to examine the multimedia based online poster project completion of the EFL learners in South Korea. The results of the study show that invariably all the students who were finding it difficult to understand the language lesson from the English language classroom clearly recognized the advantages of glogster, viewed it constructively and all the student realized that they could develop their English language skills.

Awda and Faour (2018) investigated the impact of glogster and cooperative learning as differentiation models of English as foreign language learning and science projects. The research was carried out among 18 English language teachers and 374 eighth grade students of English language. The data were collected through questionnaire and open ended interviews. The open-ended interviews were conducted in order to understand how the science and English teachers constructed meaning and how they assimilated the differentiated learning through glogster and cooperative learning. The result revealed that introducing glogster and cooperative learning can improve the comprehension level of the students to a greater level than the classroom teaching.

\section{Methodology}

\subsection{Data collection}

Data collection for the current study has been spread over a few semesters between 2009 and 2018 at VIT, Vellore, India. Convenient sampling technique has been used for choosing the subjects for this study. All the students belong to first year B.Tech programme pursuing different branches of specialization. Different language tasks have been designed to study the significance of using glogster in digital blooms taxonomy conceptual framework. The first task was spread over two weeks of instruction. The second, third and fourth tasks were spread over three months in three different semesters. The pretest and posttest scores, observation of each class and feedback obtained from the learners have been used as instruments to check the validity of the glogging tasks. 


\subsection{Glogging task}

Learning Grammar the fun way usually can channelise the learner to follow effective recall and retention strategies to learn and use the second language on digital platforms. As a teacher my goal has been to allow learners learn English and at the same time make them aware of their ability to exercise multimodal expression. The novelty of web 2.0, ease of handling and collaborative learning efforts and the reward of assignment marks makes the whole learning process fun for the learners. The syllabus and the limited internet connection at the lab do not allow the teacher to imagine such activities because the teacher alone has limited access to internet on laptop and not on all the student terminals at the lab. But the lab only supports the learners in using the system for dictionary and grammar check. Evidently there seems to be no scope for all students at the undergraduate level to have assignments on grammar the fun way using web 2.0. But with a proper schedule and plan for the students, the presentation of their grammar activity on glog was accomplished by the students.

\subsection{Description}

Students were briefed about the Glog and digital posters. There were a few students who wanted to do the glog in spite allowing them to work on alternative print based assignments. The reason for such a proposition was because of constraints in the availability of internet time in year 2009. In fact, students started working on the assignment towards the end of the semester in order gain marks as part of their internal marks. But they had been cool the whole semester without completing the assignment on time. The final submission of the assignment was delayed by most of the students. The learners lacked interest to complete their assignment for the English for Engineers II course. The last reminder turned out to be another fun filled activity when they were motivated to complete the activity using Glog, a web2.0 tool. The learners were allowed to understand their need to be responsible towards completing their assignment on grammar. The shift was that autonomy provided for their learning demanded a lot of facilitation in their learning of grammar and understanding, their ability to use and comprehend, new media and language. They were sensitized towards a more process based approach towards creating their glog on prepositions.

The worksheet on prepositions was worked out by the learners in the class when the topic Prepositions was dealt in the class. The exercise was used from the book 'A Basic English Grammar Exercises'- John Eastwood, Oxford University Press, UK,1984, 1987, Exercise BEG 141, Page 97.

Activity B: Find a photo of an outdoor scene (if possible use your own) Describe the photo using on the right/left in the foreground/background, next to and other prepositions.

The learners were given the assignment based on this activity. They were provided with a list of prepositions of place and movement like at, into, inside, outside, near, on, opposite, out of, round, through, towards, under, up, around, above, along, across, behind, below. The task was explained clearly that by using authentic real life pictures 
they should write a descriptive paragraph with a focus on appropriate use of prepositions.

The assignment was on prepositions using photographs and they had to describe the photo or write conversations. Learners were allowed to explore the album in their mobile to describe the picture using appropriate phrases. Students tried to capture or retrieve recently clicked photos. A few of them had fun clicking photos with their mobiles and transferring them on my laptop using bluetooth. While describing the people and objects in the picture they had to correctly use the prepositions and prepositional phrases. The correct use of prepositions was their focus along with other grammatical concepts. They wrote the description using appropriate phrases focusing on the correct use of prepositions. Frequency of noticing the prepositions, comprehension of meaning and using the word with accuracy has gradually increased during the glog activity.

A sample glog was created with a short video clip on prepositions from the YouTube. Similar activities where given to students to learn prepositions using YouTube videos in the consecutive classes. The Glogs were submitted by the students using the Glog educator code: 45D216.

\section{$4 \quad$ Findings}

Two classes consisting of 26 and 28 students registered for the English for Engineers - II course in two different slots under the Fully Flexible Credit System (FFCS).

A pretest on prepositions of place and movement was conducted to diagnose their level of understanding the words. The students had made mistakes with the following prepositions: under, on, off, on, opposite, at, round and across.

Table 1. Prepositions not understood by students

\begin{tabular}{|c|c|}
\hline $\begin{array}{c}\text { List of prepositions given Students } \\
\text { (wrong answer) }\end{array}$ & Correct Answer not understood by students \\
\hline Behind & under \\
\hline Near & on \\
\hline out of & off \\
\hline towards, to & on \\
\hline Opposite & across \\
\hline In & at \\
\hline From & round \\
\hline Along & across \\
\hline
\end{tabular}

One group was given print based exercises with conventional teaching of the concepts. The students were asked to check the meaning of the words in the dictionary.

The experimental group were given media based tasks on prepositions using YouTube, glogster and online dictionary for learning the prepositions. Group1 was given a picture and they were asked to write a description. Group 2 was given a glogging task. They were asked to write description using the prepositions of place and movement based on the real life photos on the glog. They were also suggested to 
upload videos on the glog. At the end of the session both the groups were subjected to a posttest to find out the effectiveness of the treatment of conventional tasks vs glog tasks for learning prepositions of place and movement.

The teacher observations of these students using web 2.0 tools and grammar explicates the whole idea that practicing teacher autonomy allows interested learners. Many activities can be adapted from the print form to the digital form. The integration of the web tool, Glogster has been quite interesting for students and the teacher. Learners have reflected that during the language classes English teachers have to introduce Web 2.0 especially to those interested in doing beyond the classroom language learning activities using the Internet. These web 2.0 language activities facilitate instruction and learning effectively.

The control group has been termed as Group 1 and the experimental group has been termed as Group 2. The data analysis for the control group is given below.

Control group - Conventional task

Table 2. Analysis of Group 1

\begin{tabular}{|c|c|c|c|c|}
\hline Group1 & N & Mean & SD & SEM \\
\hline Pretest T1 & 26 & 2.8077 & 0.6939 & 0.1361 \\
\hline Posttest T2 & 26 & 3.3365 & 1.1978 & 0.2349 \\
\hline
\end{tabular}

The T-value for this study is $t=1.9764$-.The $P$ value equals 0.0592 . So the conventional teaching and results of the pretest $\mathrm{T} 1$ and posttest $\mathrm{T} 2$ have proved to be not quite statistically significant. The learners were provided rules of preposition and cloze exercises. The control group shows some improvement in learning the concepts. The data analysis for the group 2 is given below. Group 2 is the experimental group were the students were given periodical inputs on creating the glog. Based on the digital blooms taxonomy the learning project was on synthesizing what they had learnt on prepositions in the class, viewing the YouTube video on prepositions and searching the words on the visual thesaurus https://www.visualthesaurus.com// to understand better.

$$
\text { Experimental group - Glog task }
$$

Table 3. Analysis of Group 2

\begin{tabular}{|c|c|c|c|c|}
\hline Group2 & N & Mean & SD & SEM \\
\hline Pretest T3 & 28 & 3.5000 & 0.6383 & 0.1206 \\
\hline Posttest T4 & 28 & 4.4036 & 0.5817 & 0.1099 \\
\hline
\end{tabular}

The $t$ test value is $t=5.2452$. The $P$ value is less than 0.0001 . So, this difference is considered to be extremely statistically significant. The result shows that there is significance in the use of glogster for learning prepositions. This signifies that the multimedia effect of glogster has a positive impact on learners learning process through better 'comprehensible input'(Krashen, 2003). 
So the null hypothesis is rejected and the alternate hypothesis is accepted. There is significance in using glogster, the web 2.0 tool for increasing the motivation level of L2 learners to complete English assignments on grammar.

\section{Discussion}

The students who learnt prepositions through activities related to the glog task, using real life photos, describing the photo with appropriate prepositions and using the YouTube and online visual thesaurus have understood that learning grammar contextually using relevant web tools can be an engaging and enjoyable activity. They have understood the grammatical concepts contextually. The advantages are creativity, collaborative spirit, peer learning and retention of grammar concepts. They learn by making mistakes while creating the glogs. They overcome their anxiety to express meaning through visuals and sentences in the act of glogging. A few students were Low English Proficient students. They were clinging on to the students who speak their language. They had to be grouped under peers who would help them learn English. The highly motivated learners also exhibited proficiency in the language skills. Peers who were highly motivated helped the slow learners to overcome anxiety in using new technology thereby promoting collaborative learning and social skills. These learners also exhibited good group cohesion in writing the descriptive paragraph. During such activities the highly motivated students show interest and responsibility in helping the Low English Proficient students. Majority of them had less access to internet connectivity. So they resorted to photos taken from their cameras along with the frame widgets on the glog. This experimental group outperformed the control group in the posttest T4vsT2 proving that their level of understanding has increased because of the glogging task. According to the digital blooms glogster allows the user to create using different multimedia elements by producing or reorganizing multimedia elements. The data on the following criteria were obtained from the students through a questionnaire:

\begin{tabular}{|l|c|}
\hline \multicolumn{1}{|c|}{ Criteria } & Response from Students in Percentage \\
\hline Collaborative learning efforts & $100 \%$ \\
\hline Creativity provided by Glog & $90 \%$ \\
\hline Collaborative spirit & $95 \%$ \\
\hline Peer learning & $95 \%$ \\
\hline Retention of grammar concepts & $90 \%$ \\
\hline
\end{tabular}

The response has proved that learners have $100 \%$ interest in collaborative learning efforts. While doing activities using glog, $90 \%$ of the learners have responded that they are having better retention of the grammatical concepts and better creativity in doing the activities. Majority of them have good collaborative spirit while learning with their peers. These findings have proved the effectiveness of the glogging task for language learning. Based on the technology interests of students, similar language tasks using glogs were assigned to learners in the following semesters. 


\section{$6 \quad$ Glogging Tasks}

The English for Engineers-II class of 60 students in the Winter Semester 20122013 were assigned two topics from the book Projects (OUP). They were provided glog accounts with the teacher code: 5HUHCF. The students did pairwork by conducting surveys using survey monkey.com or google forms. The communicative task given to learners was: Transcode the data with appropriate graphical representation and interpretation. All of them choose topics like Eco friendliness among students; Go Green; Reduce, Reuse, Recycle and Pocket Money survey among students.

The 2013-2014 B.Tech batch students of English for Engineers-II class were introduced to web tools and the glogging task. 108 students were given a task of preparing a digital poster using multimedia and text. This language learning task was part of their project based learning activity. All students chose topics of their choice for the project. The framework for the project was scheduled with specific deadlines. Initially, based on the data obtained from the questionnaire of certain projects the students prepared the graphical representation. They had presented the data, photos, videos and specific findings as a report. Finally, the glog also had to be presented by all the students, conveying multimodal meaning of the whole project. They were provided with teacher codes 821E6E and 81A97U.

They had to conduct survey, interviews, read articles, interpret graphical representation, write a report and present all the information and facts on glogster. Some of the topics chosen by the students are listed below:

- Critical Analysis of Business Around VIT

- Healthy Food Vs Junk Food

- Adverse Effects of Climate Change Around the World

- Indian Cultures and Languages

134 Effective English students of the 2018 batch B.Tech program were assigned a glogging task on travelogue. The web tools introduced to the students were Google maps and YouTube for virtual tours, other travel blogs, google pictures and edu.glogster. All the students were informed to write a travelogue on one country or city they prefer. They could choose real life travelling experiences, pictures, facts and videos for making their glog. The following activity was to provide directions using prepositions of place and movement to their classmate using the google maps. Directions between the airport and the nearest hotel, hotel and tourist spots or monuments, airport and the industry related any specific engineering field like mechanical, energy, manufacturing, mining, instrumentation, electronics and communication, electrical, chemical, biotechnology and civil engineering. They did a speaking activity using the details from the google map. The glog had to include their multimedia elements, link to the google map, travelogue report. Finally, the digital poster, the glog on the city had to be sent to a few prospective travelers. The students had to advertise by writing a formal letter inviting classmates to comment on their glog. 


\section{Conclusion}

Glogging as an integrative CALL activity has potential for better student engagement in learning. Proper integration of multimedia and web tools provides flexibility in learning, improving the reading skills and thereby helps in improving the learning strategies, internet search words and comprehending comments. Further learners have the opportunity to explore web tools and synthesise their ideas and create glogs. Integrative CALL tasks when designed well promote use friendliness and multimodal critical thinking skills. The effectiveness of ICALL tasks depends on how the learners are allowed to utilize various web tools, computers and media for completing their language learning tasks.

\section{$8 \quad$ References}

[1] Ahmad, K., Corbett, G., Rogers, M., \& Sussex, R. (1985). Computers, language learning and language teaching. Cambridge: Cambridge University Press. https://doi.org/10.3138/ cmlr.45.4.754

[2] Awada, G. M., \& Faour, K. H. (2018). Effect of Glogster and Cooperative Learning Differentiated Instruction on Techers' Perceptions. Teaching English with Technology, 18(2), 93-114.

[3] Baker, C., \& Wills, T. (2013). Have You Used a Glog Yet?. Teaching Children's Mathematics, 19(5), 324-327. https://doi.org/10.5951/teacchilmath.19.5.0324

[4] Benson, P. (2007). Autonomy in language teaching and learning. Language Teaching, 40, 21-40. https://doi.org/10.1017/s0261444806003958

[5] Bob Wilson. (2012) Prepositions of Placehttps:/www.youtube.com/watch?v=5UJxEin $\underline{\text { WOXs }}$

[6] Dörnyei, Z. (2005). The psychology of the language learner: Individual differences in second language acquisition. Mahwah, NJ: Lawrence Erlbaum. https://doi.org/10.1177/ 13621688070110040802

[7] Schmenk, B. (2005). 'Globalising Learner Autonomy.' TESOL Quarterly. 39(1), 107-118. https://doi.org/10.2307/3588454

[8] John Eastwood, A Basic English Grammar Exercises-, UK: Oxford University Press, 1984, 1987, Page 97

[9] Kent, D. B. (2010). Incorporating Glogster in the University EFL Curriculum. Arab World English Journal, 1(1), 130-170.

[10] Grossman, Lev. (2006). Time's Person of the Year.Time Magazine, Dec. 13, 2006.

[11] Godwin-Jones, R. (2011). Emerging Technologies Autonomous Language Learning. Language Learning \& Technology, 15(3), 4-11.

[12] Krashen, S. (2003) Explorations in Language Acquisition and Use: The Taipei Lectures. Portsmouth, NH: Heinemann.

[13] Lehrer, R. (1993). Authors of knowledge: Patterns of hypermedia design. In S.LaJoie \& S. Derry (Eds.), Computers as cognitive tools (pp. 197-227).Hillsdale, NJ: Lawrence Earlbaum.

[14] Liu, Y. (2015). Experiences and Countermeasures in a Web-Based English Teaching Project. International Journal of Emerging Technologies in Learning (iJET), 10(2), 53-57. https://doi.org/10.3991/ijet.v10i2.4480 
[15] Linek, S., Schafrick, A., \& Tochtermann, K. (2013). Just for the image? The impact of Web 2.0 for public institutions. International Journal of Emerging Technologies in Learning (iJET), 8(2013), 7-14. https://doi.org/10.3991/ijet.v8is1.2266

[16] Teach \& Learn the Prepositions of Place with this Catchy Sing-Along Song. In, On, Under, In Front of, Behind, Next to, Between. You'll be Singing it all day long. ( 2013) Retrieved Dec, 2013 from https://www.youtube.com/watch?v=QYerFOnPxu8

[17] Lessig, Lawrence. (2006). The Read-Write Society, a keynote given 15 September 2006 at the Wizards of OS4 conference, Retrieved March 1, 2012 from http://www.wizardsofos.org/programm/panels/authorship amp culture/keynote the read write society/the read write society/mp4.html

[18] Leiva, V., Sanhueza, A., Kelmansky, D. M., \& Martínez, E. J. (2009). On the glog-normal distribution and its application to the gene expression problem. Computational Statistics \& Data Analysis, 53(5), 1613-1621. https://doi.org/10.1016/j.csda.2008.04.012

[19] Mann, B. (1995). Focusing attention with temporal sound. Journal of Research on Computing in Education, 27, 402-424.

[20] Pennycook, A. 1989. The concept of method, interested knowledge, and the politics of language teaching. TESOL Quarterly, 23/4: 591-618. https://doi.org/10.2307/3587534

[21] Prensky, M. (1998). Twitch speed: Reaching younger workers who think differently. Across the Board. Retrieved March 1, 2012 from http://www.twitchspeed.com/ site/article.html

[22] .Prensky, M. (2001). Digital Natives, Digital Immigrants. On the Horizon 9, 5. Retrieved March 1, 2012 from http://www.marcprensky.com/writing/Prensky

[23] Prensky, M. (2005). "Engage me or enrage me," What today's learners demand. Retrieved March 1, 2012 from http://www.educause.edu/ir/library/pdf/erm0553.pdf.

[24] Razzaq, A., Samiha, Y. T., \& Anshari, M. (2018). Smartphone Habits and Behaviors in Supporting Students Self-Efficacy. International Journal of Emerging Technologies in Learning (iJET), 13(02), 94-109. https://doi.org/10.3991/ijet.v13i02.7685

[25] Siemens, G. (2005). Connectivism: Learning as network-creation. Retrieved March 1, 2012 from http://www.learningcircuits.org/2005/nov2005/seimens.htm

[26] Stevens, Vance. (2007).The Multiliterate Autonomous Learner: Teacher Attitudes and the Inculcation of Strategies for Lifelong Learning, Winter 2007 Independence 42, IATEFL Learner Autonomy SIG

[27] Stoeckle, K., \& Muilenburg, L. (2012, March). A New Kind of Current Event Project: Using Glogster in the Social Studies Classroom. In Society for Information Technology \& Teacher Education International Conference (pp. 3780-3784). Association for the Advancement of Computing in Education (AACE).

[28] Joshi, K.R. (2011). Learner Perceptions and Teacher Beliefs about Learner Autonomy in Language Learning. Journal of NELTA, 16, 13-29. https://doi.org/10.3126/nelta.v16i1$\underline{2.6126}$

[29] Warschauer, M. (1996). Computer-assisted language learning: An introduction. In S. Fotos (Ed.), Multimedia language teaching (pp. 3-20). Tokyo: Logos International.

[30] Warschauer, M., \& Cook, J. (1999). Service learning and technology in TESOL. Prospect, 14(3), 32-39.

[31] Warschauer, M. (2000). On-line learning in second language classroom: An ethnographic study. In M. Warschauer \& R. Kern (Eds.), Network-based language teaching: concepts and practice (pp. 41-58). Cambridge, England: Cambridge University Press. https://doi.org/10.1017/cbo9781139524735.005

[32] Warschauer, M., Shetzer, H. \& Meloni, C. (2000). Internet for English teaching. Alexandria, VA: TESOL Publications 


\section{Author}

Anitha Devi V is a faculty in the Department of English, School of Social Sciences and Languages, Vellore Institute of Technology, Vellore. She has completed her Ph.D in Computer Assisted Language Learning (CALL) from Anna University. Her area of research interests are Multimodal Language Learning with CALL and Web 2.0. She is an associate member and faculty coordinator of IEEE-PCS VIT Students' Chapter. Email id: drvanithadevi@gmail.com

Article submitted 2019-02-26. Resubmitted 2019-03-12. Final acceptance 2019-03-12. Final version published as submitted by the authors. 